\title{
Production of Fodder in a Treeless System and in Silvopastoral System in Central Argentina
}

\author{
Jose Omar Plevich $^{1}$ (D), Javier Gyenge ${ }^{2}$ (D), Angel Sanchez Delgado ${ }^{3,4,5,6}$ (D), \\ Juan Carlos Tarico ${ }^{1}$ (D), Santiago Fiandino ${ }^{1}$ (D), Marco Jesús Utello ${ }^{1}$
}

\begin{abstract}
${ }^{1}$ Grupo de Dasonomía, Departamento Producción Vegetal, Facultad de Agronomía y Veterinaria - FAV, Universidad Nacional de Río Cuarto - UNRC, Río Cuarto/Córdoba, Argentina

${ }^{2}$ Grupo de Ecología Forestal, Consejo Superior de Investigaciones Científicas y Técnicas - CONICET, Instituto Nacional de Tecnología Agropecuaria - INTA, Tandíl/Buenos Aires, Argentina

${ }^{3}$ Grupo de Pesquisa AGOMATEMÁTICA, Departamento de Matemática - DEMAT, Instituto de Ciências Exatas - ICE, Universidade Federal Rural do Rio de Janeiro - UFRRJ, Seropédica/RJ, Brasil

${ }^{4}$ Programa de Pós-graduação em Ciência, Tecnologia e Inovação em Agropecuária - PPGCTIA, Universidad Nacional de Río Cuarto - UNRC, Río Cuarto/Córdoba, Argentina

${ }^{5}$ Programa de Pós-graduação em Ciência, Tecnologia e Inovação em Agropecuária - PPGCTIA, Universidade Federal Rural do Rio de Janeiro - UFRRJ, Seropédica, Brasil

${ }^{6}$ Programa de Pós-graduação em Modelagem Matemática e Computacional - PPGMMC, Universidade Federal Rural do Rio de Janeiro - UFRRJ, Seropédica/RJ, Brasil
\end{abstract}

\begin{abstract}
This paper aims to identify the spatial and temporal distribution of net aerial primary production (NAPP) of oats and sorghum in silvopastoral systems (SPS) and in a treeless situation (TLS), in Southern Cordoba, Argentina. The silvopastoral systems are composed of three woody cultures (Pinus elliottii, Eucalyptus viminalis and Quercus robur), and two grass species (Avena sativa and Sorghum sudanense). NAPP of Avena sativa and Sorghum sudanense were lower in the silvopastoral systems than in the treeless situation. However, there were also differences in terms of NAPP according to the tree species, and these differences were related to the intensity of competition between trees and grasses. Pinus elliottii and Quercus robur were less competitive than Eucalyptus viminalis, which might be associated with their morphophysiological differences, their differential growth rate and their differences in terms of phenology. Finally, facilitation effects between trees and grasses were also identified under certain conditions.
\end{abstract}

Keywords: agroforestry; forage crop; competition; facilitation. 


\section{INTRODUCTION}

Agroforestry is a set of land management techniques that combines trees and shrubs, either with livestock, or with crops. Therefore, agroforestry systems are diversified and multi-layered land use systems in which trees are cultivated in association, whether planned or not, with annual crops or pastures, simultaneously or sequentially. In this type of systems, complementarity in the use of resources between the herbaceous stratum and the woody component is the key to success (Ong \& Leakey, 1999). The performance of the vegetation, which is simply the result of the exchange of matter and energy between the vegetation and the environment, is often described through net aerial primary productivity (NAPP) (Ospina et al., 2012). NAPP is then used as an integrating variable for the performance of the ecosystem and reflects the energy input to the food chain (Massa et al., 2016).

The productive result of an agroforestry system depends on the balance between the processes of competition and facilitation. These interactions can be facilitative: through carbon enrichment, interception of nutrients that are leaching deep into subsoil, improvements in soil physical qualities, and water supply through hydraulic elevation; complementary: if deep-rooted trees can use resources that are not accessible to crops (increasing the use of resources by the whole system); competitive: if trees use limiting resources from the same source as undergrowth plants (Fernández et al., 2008). In some cases, the negative effects of allelopathy can also be observed (Plevich et al., 2016). The magnitude and direction of these processes will depend on the interaction between the abiotic limitations of the site and the ecophysiological plasticity of the cultivated species (Caballé, 2013).

Therefore, it is necessary to explore the synergies in the association tree-crop through evaluating different plant species under specific soil and climate conditions. In the present case, these relationships were studied by measuring the total net aerial primary production of a silvopastoral system composed of three woody species (Pinus elliottii, Eucalyptus viminalis and Quercus robur), a winter C3 grass (oats, Avena sativa) and a summer C4 grass (sorghum, Sorghum sudanense). The objective of this research was to determine the spatial and temporal distribution of the net primary aerial production of oats and sorghum in silvopastoral systems (SPS), comparing it with a treeless situation (not afforested; TLS).

\section{MATERIAL AND METHODS}

This study was carried out in three silvopastoral systems established during 1998 (the trees had 15 years old at the moment of the measurements), each composed of a different woody species: Pinus elliottii, Eucalyptus viminalis and Quercus robur, and in a neighboring treeless situation; both under similar soil conditions, and located in "La Aguada" rural establishment (32 $58^{\circ} 19.52^{\prime \prime}$ ' $64^{\circ} 39^{\prime} 4.86^{\prime \prime} \mathrm{W}, 550 \mathrm{~m}$ above sea level). This experimental center belongs to the National University of Rio Cuarto and is located in the rolling plain in the Southwest of the province of Córdoba, Argentina. The climate of the region is Monsoon type, with warm and wet summers, and cold and dry winters. Average annual rainfall is between $700-800 \mathrm{~mm}$ (with approximately $80 \%$ of those concentrated in spring-summer). Maximum and minimum annual average temperatures are $23^{\circ} \mathrm{C}$ and $9.1^{\circ} \mathrm{C}$, respectively, with an annual mean temperature of $16^{\circ} \mathrm{C}$. The topography of the region corresponds to a rolling plain environment, where the average slope is around $1.5 \%$ and the predominant soils are deep, well drained and sandy Haplustolls, with a water retention capacity of $100 \mathrm{~mm}$ to $1 \mathrm{~m}$ in depth (Plevich et al., 2016).

The silvopastoral systems were designed to produce forage crops in alleys of $20 \mathrm{~m}$ width, delimited by parallel tree curtains, which are constituted by two rows of trees arranged in a plantation frame of $2 \times 2 \mathrm{~m}$, with East-West orientation. In order to determine the distribution of the net primary production of winter (oats) and summer (sorghum) grasses in the alleys of silvopastoral systems, samples were taken at different distances from the tree trunk and at different exposures (south: S; north: N): $2.5 \mathrm{~m} \mathrm{~S} ; 5 \mathrm{~m} \mathrm{~S} ; 7.5 \mathrm{~m} \mathrm{~S} ; 10 \mathrm{~m}$ - center of the alley; $7.5 \mathrm{~m} \mathrm{~N} ; 5 \mathrm{~m} \mathrm{~N} ; 2.5 \mathrm{~m} \mathrm{~N}$, crossing the alley in direction N-S. In the treeless situation (TLS), 7 samples were randomly collected (Figure 1).

The forage collected was oven-dried at $65{ }^{\circ} \mathrm{C}$ to determine dry matter weight (DM). Samples were taken twice during the growth cycle of each grass species: 1- in April and October for Avena sativa, 2- in January and March for Sorghum sudanense. After 


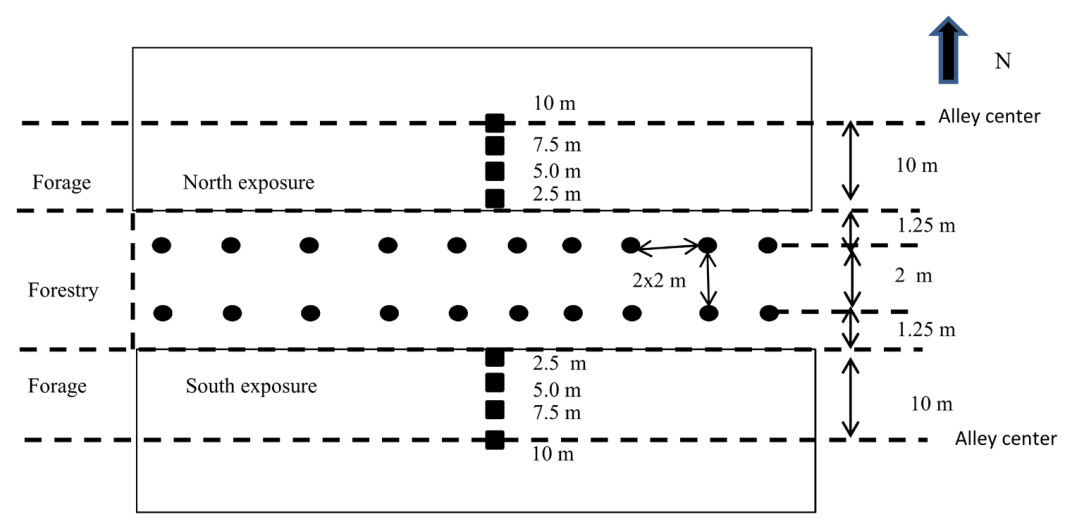

Figure 1. Diagram of the silvopastoral systems design $\left(490 \mathrm{~m}^{2}\right)$.

each sampling, the alleys and the TLS were grazed by heifers. Then, the grass was cut with a lawn mower in order to improve regrowth.

Finally, the average production of each alley combination (tree-crop) was estimated through a weighted average ( $\hat{\mathrm{u}}$ ), dividing the alley in seven parts (classes) of the same area $(\mathrm{i}=1 \ldots \mathrm{n})$, according to the mean distance to the tree trunk and the exposure $(\mathrm{N}, \mathrm{S})$, (Equation 1).

$\hat{u}=\frac{\sum_{i=1}^{n} p_{i}^{*} s_{i}}{\sum_{i=1}^{n} s_{i}} * 10$

Where:

$\hat{\mathrm{u}}-$ Represents the average grass NAPP of the alley (KgDM.ha-1 ${ }^{-1}$.

$p_{i}$ - Represents the NAPP of the "i" class (grDM.m²).

$s_{i}$ - Represents the area occupied by the "i" class $\left(\mathrm{m}^{2}\right)$.

To understand the response of forage production in the treatments proposed in each of the points where NAPP data was taken, water content of the soil and photosynthetically active radiation levels were also measured.

The soil water content was estimated considering 3 repetitions for each horizon of the soil profile and up to $1 \mathrm{~m}$ depth. The water in the soil profile was taken at the beginning and end of the cycle of each crop (oats and sorghum). Using the data of the gravimetric humidity of the soil and employing the method proposed by Gil \& Martelotto (1993). Those values were expressed in useful water for plants (mm).
The photosynthetically active radiation (PAR) was measured by a Ceptometer. Measurements were made in all seasons, in order to cover the cycle of the forage species. The data was taken in each position every hour, starting the records at 9 am and ending at $6 \mathrm{pm}$.

The experimental design corresponds to a split plot experiment, and the statistical comparisons were carried out by doing an ANOVA, using the linear mixed models' module in Infostat statistical software (Di Rienzo et al., 2013). The means were compared through the Fisher LSD test.

\section{RESULTS AND DISCUSSION}

\subsection{Characteristics of silvopastoral systems}

At the time of the trial, the silvopastoral systems were 15 years old and the size of crowns expressed through the average of their radius were $3.45 \pm 1.31 \mathrm{~m}$ (Eucalyptus viminalis); $2.08 \pm 1.08 \mathrm{~m}$ (Pinus elliottii) and $2.63 \pm 1.30$ (Quercus robur), observing a variation according to whether the crowns were in the $\mathrm{N}$ or $\mathrm{S}$ exposure of the row of trees, being much more marked in pine and oak (Table 1).

\subsection{Net primary production of Avena sativa}

In the first cut of oat, the distribution of NAPP along the alley was very similar in the systems integrated by both pines and oaks. There were statistically significant differences ( $\mathrm{p} \leq 0.05)$ in the NAPP according both to the exposure and the distance from the tree trunk (Figure 2A). On the other hand, in the Eucalyptus 
Table 1. Radius of the tree crowns in silvopastoral systems in the rolling plain of central Argentina.

\begin{tabular}{ccccccc} 
SPS species & Exposure & Maximum & Average & Minimum & $\begin{array}{c}\text { Typical } \\
\text { deviation }\end{array}$ & $\begin{array}{c}\text { Measured } \\
\text { trees }\end{array}$ \\
\hline Eucalyptus & North & 5.70 & 3.50 & 1.60 & 1.18 & 20 \\
\hline Eucalyptus & South & 6.30 & 3.40 & 1.0 & 1.43 & 18 \\
\hline Pine & North & 3.50 & 2.54 & 1.20 & 0.62 & 29 \\
Pine & South & 2.75 & 1.62 & 0.96 & 0.48 & 22 \\
Oak & North & 3.80 & 2.30 & 1.20 & 0.70 & 27 \\
\hline Oak & South & 4.30 & 2.96 & 1.40 & 0.73 & 27 \\
\hline
\end{tabular}
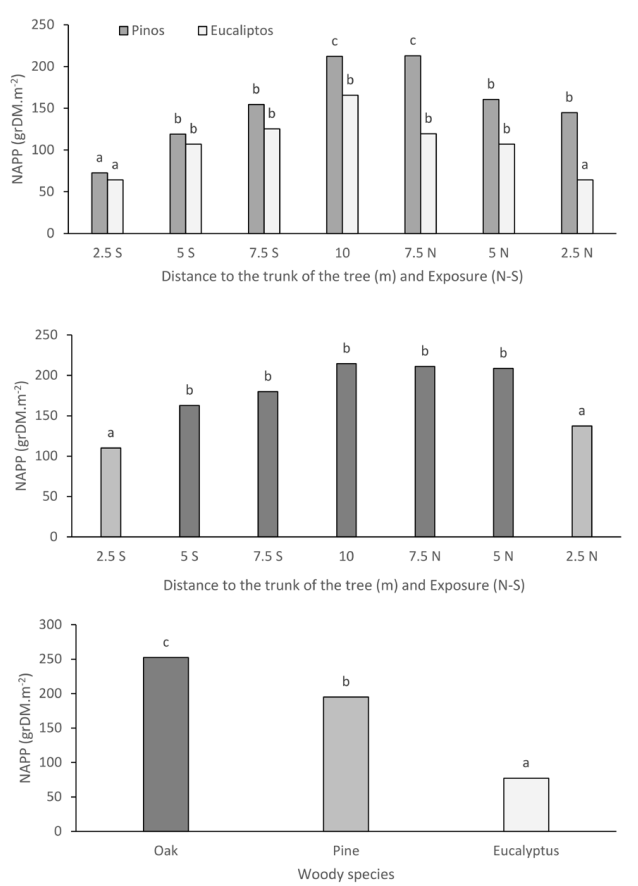

Figure 2. NAPP of Avena sativa (grDM.m-2) in the alley of silvopastoral systems for the first grazing cycle (A). NAPP of Avena sativa $\left(\mathrm{grDM}_{\mathrm{m}}{ }^{-2}\right)$ in the alley of silvopastoral systems for the second grazing cycle (B) y (C). Different letters mean significant differences between treatments $(P<0.05)$.

silvopastoral system, there were no differences between North and South exposures, but there was a stratification of the NAPP according to the distance from the trees $(\mathrm{p} \leq 0.05)$ (Figure 2A). In both pines and oaks systems, a higher average forage production was found in the Northern exposure (182.83 grDM.m $\left.{ }^{-2}\right)$ than in the Southern exposure (139.56 grDM.m ${ }^{-2}$ ).

In addition, two strata with different NAPP were found in relation to the distance from the tree in the Northern exposure (0-5 $\mathrm{m}$ and 5-10 $\mathrm{m}$ ), and three different strata in the Southern exposure (0-2.5m, 2.5-7.5 m, 7.5-10 m) (Figure 2A). These results might be explained by the higher level of radiation that affects the Northern exposure (Figure 3C y D), particularly in the hours close to noon, when the azimuthal angle of the sun causes the sun's rays to fall perpendicular to the alleys direction (Figure 3A) (Pezzopane et al., 2015). However, in the area closest to the tree trunk, the effects of competition for water and radiation would seem to act together to determine the biomass production of the grasses (Figure 4) (Casanova et al., 2007; Rusch et al., 2014).

In the silvopastoral system integrated by Eucalyptus, despite the greater attenuation of the radiation in the Southern exposure (Figure 3B), the average NAPP in both exposures reached 115grDM.m ${ }^{-2}$. However, the forage production was significantly higher from a distance of $5 \mathrm{~m}$ from the tree's trunk (Figure 2A).

Unlike what happened in both pine and oak systems, in the eucalyptus system the greatest restrictions might have been due to allelopathic effects (Espinosa García, 1996; Plevich et al., 2016) and competition for water, even for a relatively humid period (Figure 4) (autumn of 2015). At the time the oat was sown, the soil profile was at field capacity (100mm to $1 \mathrm{~m}$ depth; Figure $4 \mathrm{~A}$ ), and from that moment to the first forage cut, $227 \mathrm{~mm}$ of precipitation was accumulated (Figure 5).

In relation to these results, Schaller et al., (2001) tried to reduce the lateral growth of eucalyptus (Eucalyptus deglupta) roots by intercropping the trees with competitive grasses, but they observed that the roots of the trees were even more superficial in the intercropped treatments. These authors highlighted that eucalyptus trees have a strong competitive capacity for the soil resources. In the case under study, this competitive capacity might be even stronger since we worked with larger and older trees (normal average diameter of $29.5 \mathrm{~cm}$ and $15.7 \mathrm{~m}$ of total height). 

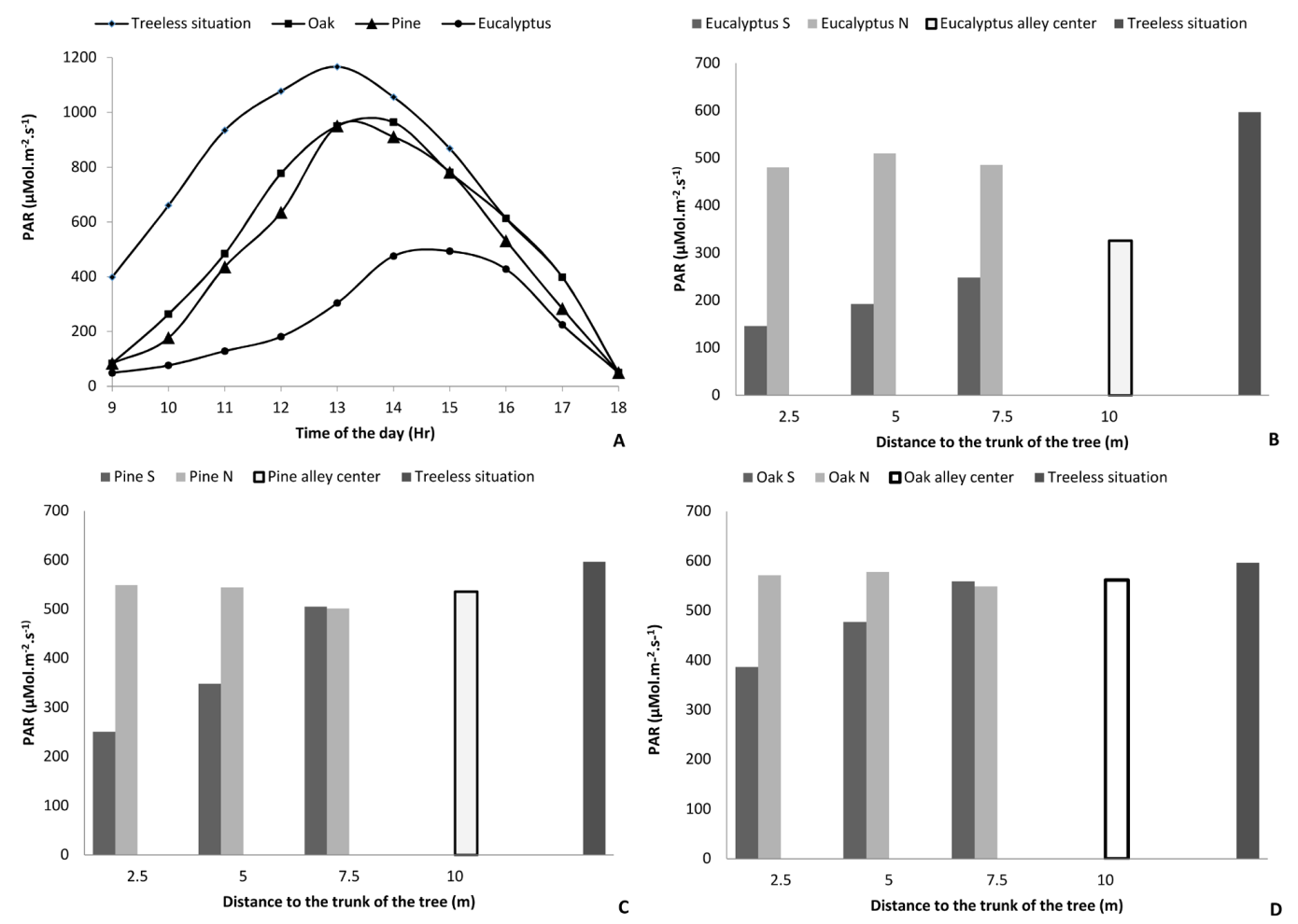

Figure 3. Dynamics of the photosynthetically active radiation during the autumn (PAR in the silvopastoral systems (SPS): A) Average hourly PAR in the SPS. B) Average daily PAR in the North and South exposures of the SPS alley with eucalyptus. C) Average daily PAR in the North and South exposures of the SPS alley with pine. D) Average daily PAR in the North and South exposures of the SPS alley with oak.
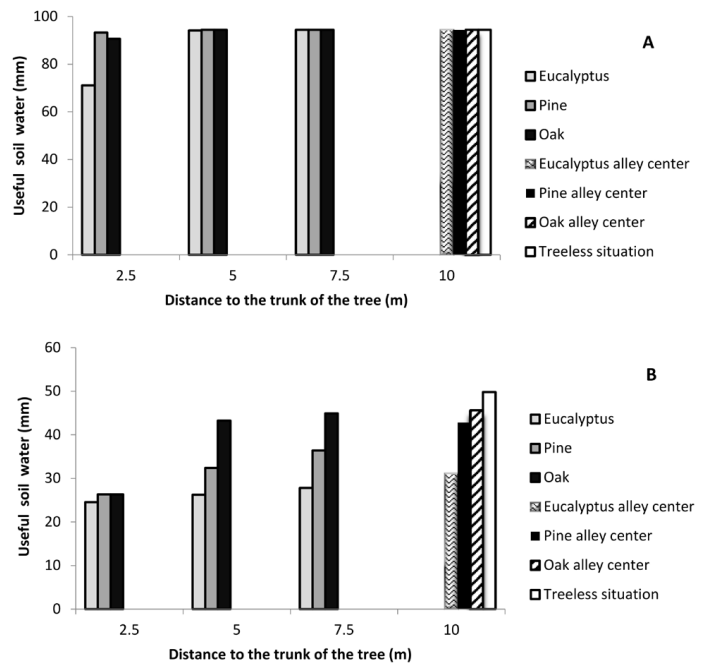

Figure 4. Useful soil water (1m depth): A) Useful soil water in silvopastoral systems and in the treeless situation at the beginning of the $1^{\text {st }}$ cycle of oat growth. B) Useful soil water in silvopastoral systems and in the treeless situation at the end of the $1^{\text {st }}$ cycle of oat growth.
In the second cut of oat, the distribution of NAPP along the alley followed the same stratification pattern in the three silvopastoral system combinations (Figure 2B). Contrary to what was found before the first grazing, NAPP differed only according to the distance from the tree stem $(\mathrm{p} \leq 0.05)$ and not due to exposure. Sampling points at $2.5 \mathrm{~m}$ from the tree stem in both exposures presented lower biomass yields. The average oat biomass production at the central positions $(5 \mathrm{~m}, 7.5 \mathrm{~m}$ and $10 \mathrm{~m})$ of the three system combinations was $195.34 \mathrm{grDM} . \mathrm{m}^{-2}$, while at the extreme positions (2.5m) was 123.63grDM.m-2.

The period between the first and the second grazing lasted from the end of April until the end of October, when growth rates were reduced due to the attenuation of the photosynthetically active radiation (Figure 6) and the consequent decrease in temperature during the winter and the water restrictions at the beginning of spring (Figure 7). 


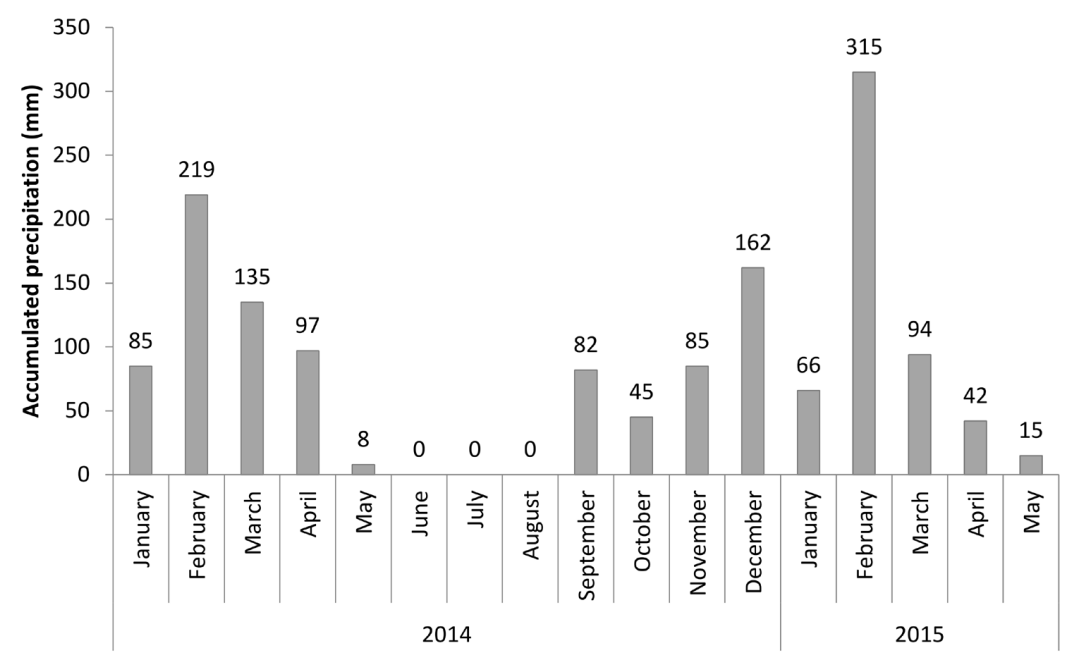

Figure 5. Accumulated rain (mm) in the months between January 2014 and May 2015.
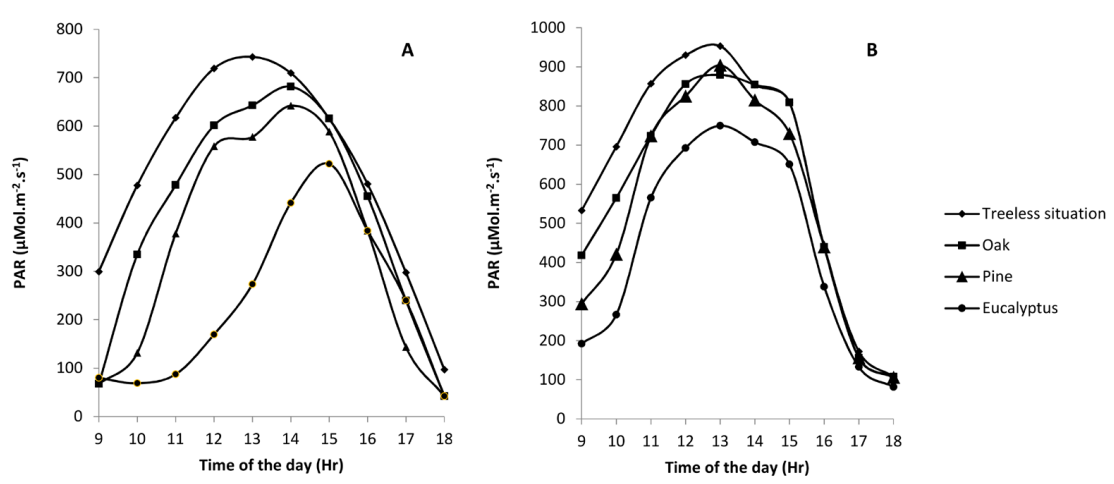

Figure 6. Photosynthetically Active Radiation (PAR) in the SPS: A) during the winter B) during the spring.

In contrast to what happened during the fall, the water resource was more limiting for the growth of oats than the shadow levels, since in the period from May to October the accumulated rainfall was only $135 \mathrm{~mm}$ (Figure 5).

The positions that showed inferior NAPP values were the closest to the tree stem, and this is where the competition for water between the roots of the woody and the herbaceous species is strongly expressed. In that sense, Guevara Escobar et al. (2012) found that the soil moisture content in the near surface soil horizons decreased by an average of $8 \% \mathrm{v} / \mathrm{v}$ at $1 \mathrm{~m}$ of an eucalyptus tree row, which resulted in decreases in the biomass production of the pasture close to $40 \%$.

Although the distribution pattern of the NAPP according to the distance from the tree was the same in the three silvopastoral systems, the average biomass production of each system combination was different (Figure 2C). The average NAPP in the oak's alley was 23\% and $70 \%$ higher than that of the pines and eucalyptus, respectively. These differences can be explained by the fall of the oak leaves in autumn (deciduous species), which improves the penetration of photosynthetically active radiation (PAR) in the alleys during winter and spring, when foliation begins (Figure 6). In addition, during this period competition for water between the tree and the herbaceous is almost non-existent. Therefore, there was a complementary use of resources between the herbaceous component and the woody component in the Quercus robur / Avena sativa system that could be explained by its complementary phenology. Silvopastoral systems have $18 \%$ less area occupied by 

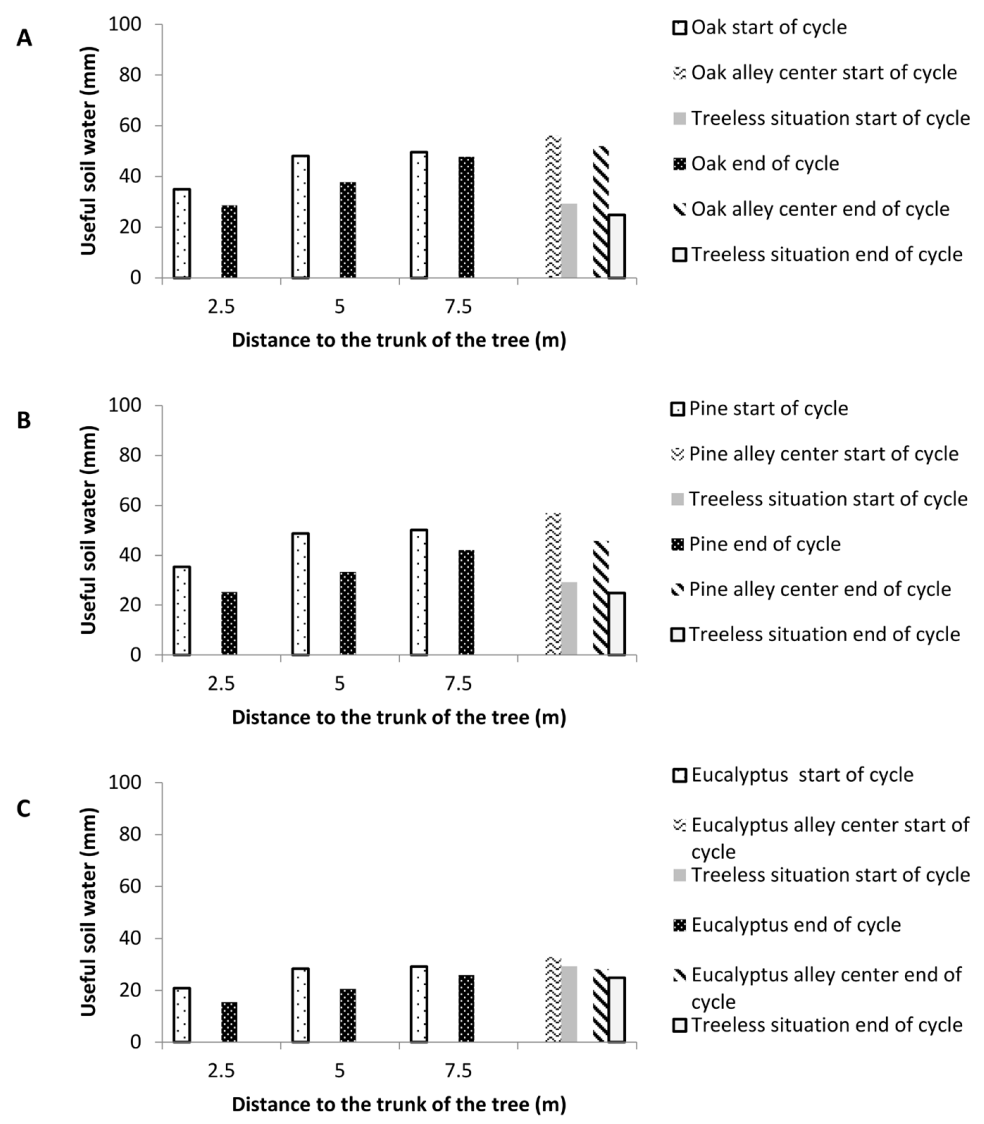

QEucalyptus start of cycle
$\approx$ Eucalyptus alley center start of
cycle
$\square$ Treeless situation start of cycle
Eucalyptus end of cycle
Eucalyptus alley center end of
cycle
QTreeless situation end of cycle

Figure 7. Useful soil water ( $\mathrm{mm}$ ) during the second cycle of oats (spring): A) SPS Eucalyptus-oats B) SPS Pine-oats C) SPS Oak-Oats

Table 2. Total net aerial primary production (NAPP) and in each growth cycle of Avena sativa.

\begin{tabular}{|c|c|c|c|c|c|c|}
\hline \multirow[b]{2}{*}{ System } & \multicolumn{2}{|c|}{ First grazing cycle } & \multicolumn{2}{|c|}{ Second grazing cycle } & \multicolumn{2}{|c|}{ Total } \\
\hline & $\begin{array}{c}\text { NAPP } \\
\left(\mathrm{Kg} \mathrm{DM} \mathrm{ha}^{-1}\right)\end{array}$ & $\begin{array}{l}\% \text { of the } \\
\text { treeless } \\
\text { situation }\end{array}$ & $\begin{array}{c}\text { NAPP } \\
\left(\mathrm{Kg} \mathrm{DM} \mathrm{ha}^{-1}\right)\end{array}$ & $\begin{array}{l}\% \text { of the } \\
\text { treeless } \\
\text { situation }\end{array}$ & $\begin{array}{c}\text { NAPP } \\
\left(\mathrm{Kg} \mathrm{DM} \mathrm{ha}^{-1}\right)\end{array}$ & $\begin{array}{c}\% \text { of the } \\
\text { treeless } \\
\text { situation }\end{array}$ \\
\hline Eucalypt-oats & $1,148.5$ & 28.93 & 663.45 & 14.90 & $1,811.95$ & 21.51 \\
\hline Pine-oats & $2,428.8$ & 61.18 & $1,599.74$ & 35.93 & $4,028.54$ & 47.83 \\
\hline Oak-oats & $2,428.8$ & 61.18 & $2,068.29$ & 46.45 & $4,497.09$ & 53.39 \\
\hline Treeless situation & $3,970.0$ & 100.00 & $4,452.40$ & 100.00 & $8,422.40$ & 100.00 \\
\hline
\end{tabular}

crops than the TLS, since that portion of land is occupied by the trees. After estimating and adjusting the average production of each alley combination (tree-crop), it was found that for the first grazing cycle, the forage production of the TLS was $50 \%$ higher than the three systems average. Oat productivity decreased by $40 \%$ in the Pinus elliotti and Quercus robur systems, and 71\% in the Eucalyptus viminalis system (Table 1). The NAPP on the second grazing cycle, was 53, 64 and $85 \%$ lower than in the TLS in the Quercus robur, Pinus elliotti and Eucalyptus viminalis systems, respectively (Table 2).

In terms of total production, the NAPP of Avena sativa in the SPS was 78, 52 and $47 \%$ lower than in the TLS, depending on whether the woody species was Eucalyptus viminalis, Pinus elliottii or Quercus robur, respectively.

These differences in the total biomass production between the treeless situation and the silvopastoral 
systems could be explained by: 1- the decrease in the cultivated area (due to the presence of trees); 2 - a differential affectation of the oat crown rust (Puccinia coronata) that was more intense within the alleys; and 3- the competition for resources between the woody and the herbaceous species (mainly light and water), the intensity of which is directly related with the distance to the tree trunk. Holmgren et al. (1997) argue that the light limitation is greater than the soil moisture limitation in humid environments and prevents the favorable effects of a slight increase in soil moisture under the canopy (shading may decrease the water losses). On the other hand, water constraints are more important in dry environments than light limitations, and therefore, decreases in the PAR that reaches the understory and may be compensated by increments in soil moisture. In the case under study, the exposure only influenced biomass production during the first grazing cycle (autumn), which may indicate that the differential penetration of PAR in the Northern and Southern fractions of the alley only had an effect during a period without water restrictions. In this sense, since the oat growth was limited by water deficit conditions between the first and the second grazing, we did not find an effect of the exposure on the NAPP of the second oat cut, which means that the water constraints became more important than the differential shading conditions. This agrees with what was found by authors like Bahamonde et al. (2012), who compared the NAPP of the understory of Nothofagus antarctica forests with that of the grasslands in the Argentinian Patagonia; and identified different results according to the characteristics of the area. In areas with high soil water availability, the NAPP was maximum at open air (grassland) and decreased linearly when tree cover increased; while in areas that presented soil water limitations, the maximum NAPP was reached with an intermediate tree coverage.

\subsection{Net primary production of Sorghum sudanense}

The results obtained on the first cut of sorghum showed differences in the NAPP according to both the distance to the tree and the exposure in all the SPS combinations (Figure 8A).
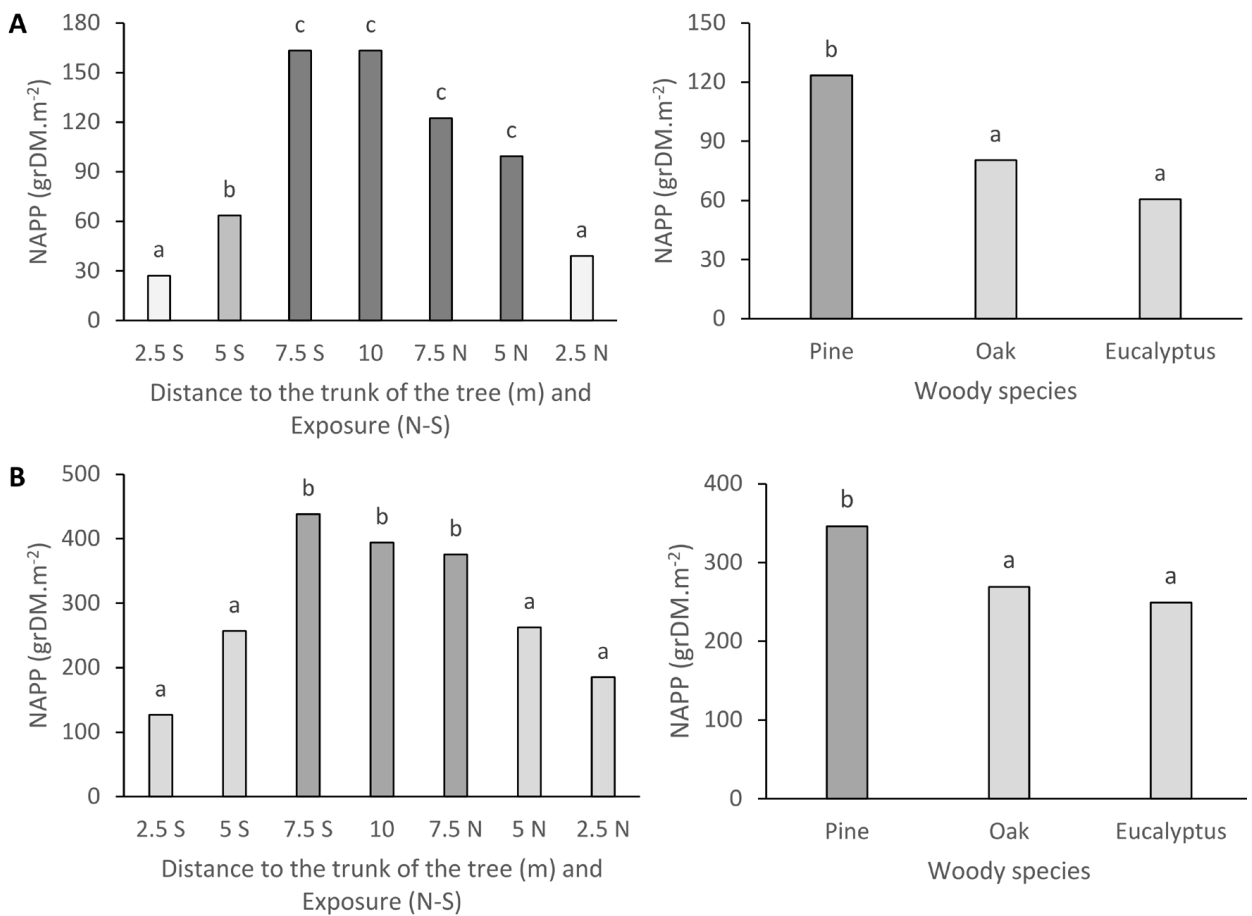

Figure 8. NAPP of Sorghum sudanense (grDM.m ${ }^{-2}$ ) in different positions within the alley of silvopastoral systems, and according to the accompanying woody species, for the first grazing cycle (A) and for de second grazing cycle (B). 
The biomass production was lower at $2.5 \mathrm{~m}$ from the trunk at both exposures, and at $5 \mathrm{~m}$ on South exposure. In the rest of the alley, the values did not differ significantly from each other. After the regrowth (and before the second grazing), a decrease in NAPP was found at 2.5 and $5 \mathrm{~m}$ from the tree trunk in both exposures (Figure 8B). The differences found may be explained based on the effect of trees on the incident PAR and the availability of soil water. First, the incident PAR decreases as the sampling point is closer to the trees (Figure 9). This restriction is especially important for the cultivation of sorghum, since it is a C4 species, which needs high light intensity to be able to grow at higher rates (Zelada \& Ibrahim, 2005). Further, we found that lower soil water contents in the same sampling points where the NAPP decreased (Figure 10A) in every measurement during the sorghum growth cycle. This coincides with that observed by authors such as Guevara Escobar et al. (2012), who found lower water contents in the upper soil horizons in the SPS than in the treeless situation, indicating competition for this resource between trees and grasses.

However, in the central positions of the alley, the average NAPP is similar (or even higher) to that of the TLS, which may indicate the occurrence of facilitation processes between trees and grasses. In this case, the woody species might have mitigated the water losses (facilitation) in the center of the alley, through
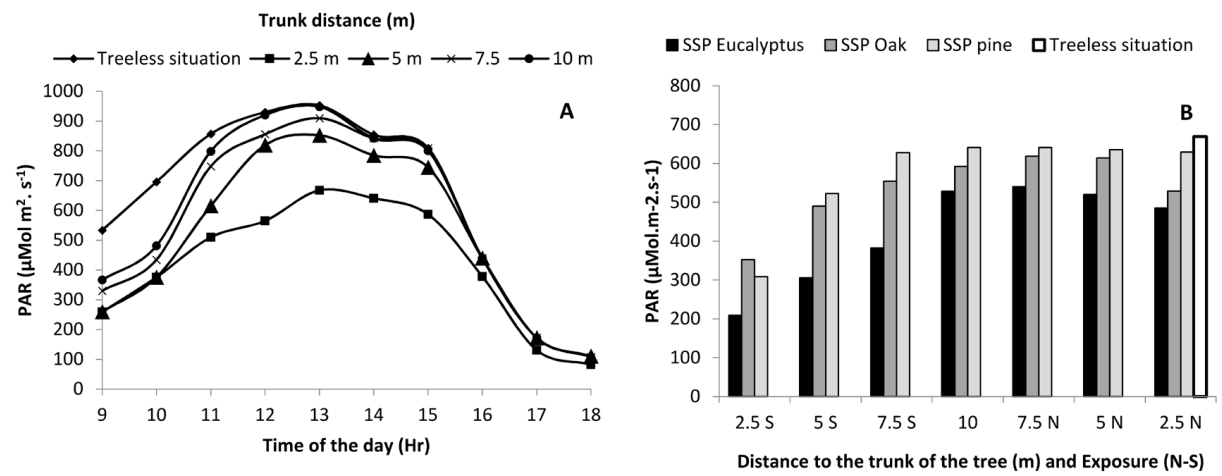

Figure 9. Dynamics of photosynthetically active radiation (PAR) during the first sorghum cycle (late spring) in silvopastoral systems (SPS): A) Hourly PAR in the SPS. B) Average daily PAR in the North and South exposures of the SPS alley.
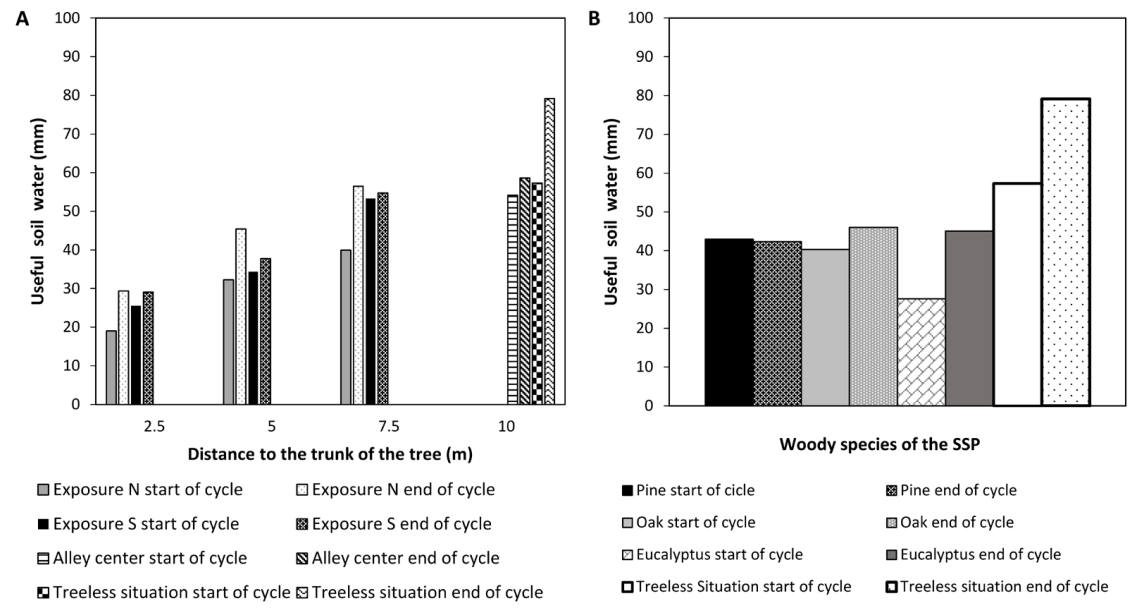

Figure 10. Useful soil water ( $1 \mathrm{~m}$ depth) during the first cycle of the sorghum crop A) Useful water at different distances from the trunk and exposure in the alleys of the SPS B) Useful water in the different SPS. 
reducing the intensity of the winds (and therefore its desiccant effect) and the evaporation (due to the shading) (Caballé, 2013).

Although the spatial distribution of the NAPP was similar in all the SPS, the biomass production of Sorghum sudanense was 43\% and 37\% (first and second cut, respectively) higher in the pine-sorghum association than the average of the oak-sorghum and eucalyptus-sorghum associations (Figures 8A and 8B). These results may be attributed to the differences in the density of the canopy between the tree species, because pines allow a greater penetration of solar radiation to the alley compared to the eucalyptus and oaks (Figure 9). As mentioned previously, the species with C4 metabolism, such as sorghum, are very sensitive to decreases in PAR (Jose et al., 2004).

In comparison with the results obtained during the first growth cycle, the NAPP values of sorghum were more similar between the SPS and the TLS in the second cycle.

During the first cycle, from the sorghum planting to the first grazing, the accumulated rainfall was $228 \mathrm{~mm}$ and, on average, the useful water of the soil in the SPS was lower than in the situation without trees (Fig 10A), whereas in the second cycle, the cumulative rainfall was $409 \mathrm{~mm}$, and the useful water in the soil was higher. The SPS and the treeless situation were similar (Figure 11). Therefore, competition for water between trees and pastures may have been greater during the first growth cycle than in the second cycle.

In addition, the soil water content at the beginning of the first growth cycle was below field capacity due to the extraction of the predecessor crop (Figure 10), which may also have caused problems in the germination and the establishment of sorghum seedlings near the trees stems (Baruch \& Fisher, 1991). This effect was more relevant in the system with eucalyptus than in the pine and oak systems. On the other hand, since there were less water restrictions in the soil in the second cycle of sorghum, after regrowth competition for this resource between trees and grass could have been less important than the decrease in PAR due to shading, which probably explains the spatial variability of the NAPP (Zelada \& Ibrahim, 2005).

Finally, the average NAPP on the first growth cycle was 71,81 and $86 \%$ lower in the SPS than in the TLS for Pinus elliotti, Quercus robur and Eucalyptus viminalis systems, respectively (Table 3). However, the biomass production differences between the SPS and the TLS were less marked after regrowth. The NAPP in the SPS was reduced by 28,44 or $48 \%$ in relation to that of the TLS on the Pinus elliotti, Quercus robur and Eucalyptus viminalis systems, respectively (Table 3 ). In terms of total production, the NAPP of the SPS was 66, 61 and 48\% lower than the TLS on the Eucalyptus
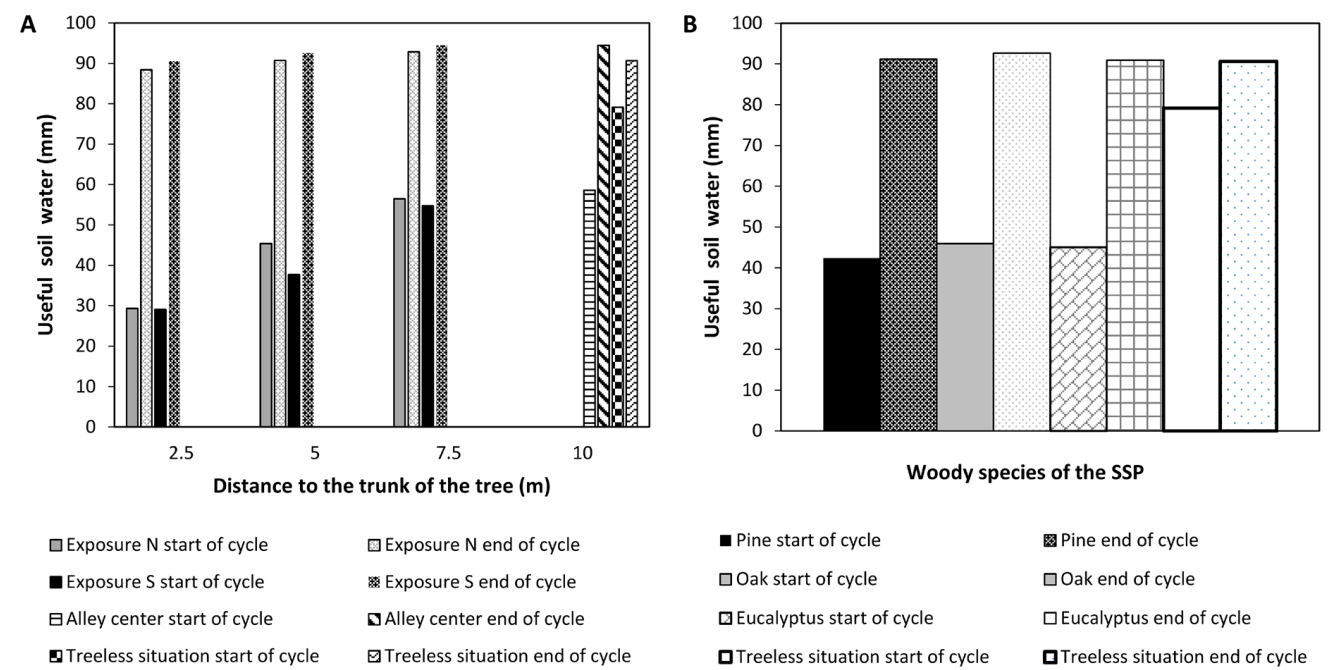

Figure 11. Useful soil water (1m depth) during the second cycle of the sorghum crop A) Useful water at different distances from the trunk and exposure in the alleys of the SPS B) Useful water in the different SPS. 
Table 3. Total net aerial primary production (NAPP) and in each growth cycle of Sorghum sudanense.

\begin{tabular}{|c|c|c|c|c|c|c|}
\hline \multirow[b]{2}{*}{ System } & \multicolumn{2}{|c|}{ First grazing cycle } & \multicolumn{2}{|c|}{ Second grazing cycle } & \multicolumn{2}{|c|}{ Total } \\
\hline & $\begin{array}{c}\text { NAPP } \\
\left(\mathrm{Kg} \mathrm{DM.ha}^{-1}\right)\end{array}$ & $\begin{array}{c}\% \text { of the } \\
\text { treeless } \\
\text { situation }\end{array}$ & $\begin{array}{c}\text { NAPP } \\
\left(\mathrm{Kg} \mathrm{DM.ha}^{-1}\right)\end{array}$ & $\begin{array}{l}\% \text { of the } \\
\text { treeless } \\
\text { situation }\end{array}$ & $\begin{array}{c}\text { NAPP } \\
\left(\mathrm{Kg} \mathrm{DM.ha}^{-1}\right)\end{array}$ & $\begin{array}{l}\% \text { of the } \\
\text { treeless } \\
\text { situation }\end{array}$ \\
\hline Eucalypt-sorghum & 495.0 & 14.28 & $2,043.11$ & 51.86 & $2,538.11$ & 34.27 \\
\hline Pine-sorghum & $1,006.9$ & 29.05 & $2,837.53$ & 72.02 & $3,844.43$ & 51.91 \\
\hline Oak-sorghum & 655.74 & 18.92 & $2,206.46$ & 56.00 & $2,862.20$ & 38.65 \\
\hline Treeless situation & $3,466.0$ & 100.00 & $3,940.00$ & 100.00 & $7,406.00$ & 100.00 \\
\hline
\end{tabular}

viminalis, Quercus robur and Pinus elliottii systems, respectively (Table 3).

Nevertheless, it is possible that an improvement in soil moisture conditions at the time of planting might have increased significantly the NAPP in the first growth cycle, reducing these differences in forage production. Additionally, there is always an $18 \%$ of the area of the SPS occupied by the trees, which presumes a reduction of equal magnitude in forage production per area unit when the NAPP of both alleys and treeless situation is the same. This means that, for the pine-sorghum system, the $28 \%$ reduction in NAPP on the second grazing cycle can be decomposed by an $18 \%$ corresponding to the area occupied by the trees and $10 \%$ attributable to the competition between trees and grasses.

\section{CONCLUSION}

The NAPP of Avena sativa and Sorghum sudanense was different between the silvopastoral combinations tested in all the measurements performed. In general terms, the forage production was higher in the pine-grass and in the oak-grass associations than in the eucalypt-grass. In the eucalyptus system, besides the great competition capacity of this tree species, allelopathy may also explain the lower NAPP found. Although the results obtained in both pine and oak systems were similar, the winter forage production was higher in the oak SPS, whereas the summer forage production was higher in the pine SPS.

The NAPP of the treeless situation was always higher than those of the SPS, but the magnitude of these differences depended on the climate conditions during the growth cycles (especially accumulated precipitation). In general terms, the effects of sunlight competition were more evident when water availability was not limiting, while the soil moisture explained better the differences in forage production after relatively dry periods. In this sense, the fast water depletion of the upper soil horizons in the positions closest to the trees $(2.5$ and $5 \mathrm{~m})$ also affected the establishment of the grass seedlings and delayed their development. Facilitation processes were only detected in the central positions of the alleys during sorghum second growth cycle, where the better water economy of the alleys may explain that the NAPP was superior to that of the treeless situation. Finally, the fact that the trees occupied $18 \%$ of the systems surface produces the effect that, as minimum, the SPS have to produce $18 \%$ more forage in the rest of the area to compensate the difference in terms of NAPP.

\section{ACKNOWLEDGEMENTS}

We are grateful to the UNRC, UFRRJ and AER INTA Tandil.

\section{SUBMISSION STATUS}

Received: 21 oct., 2015

Accepted: 30 jun., 2018

\section{CORRESPONDENCE TO}

\section{Angel Sanchez Delgado}

Departamento de Matemática - DEMAT, Instituto de Ciências Exatas - ICE, Universidade Federal Rural do Rio de Janeiro - UFRRJ, Km 7, Rodovia BR 465, CEP 23851-970, Seropédica, RJ, Brasil

e-mail: asanchez@ufrrj.br

\section{FINANCIAL SUPPORT}

Nothing to declare 


\section{REFERENCES}

Bahamonde HA, Peri PL, Álvarez R, Barneix A. Producción y calidad de gramíneas en un gradiente de calidades de sitio y coberturas en bosques de Nothofagus antarctica (G. Forster) Oerst. en Patagonia. Ecología Austral 2012; 22: 62-73.

Baruch Z, Fisher M. Factores climáticos y de competencia que afectan el desarrollo de la planta en el establecimiento de una pastura. In: Lascano CE, Spain JM, editores. Establecimiento y renovación de pasturas. Cali: Centro Internacional de Agricultura Tropical; 1991.

Caballé G. Efecto interactivo de la defoliación del estrato herbáceo y la cobertura del estrato arbóreo sobre el crecimiento del estrato herbáceo en sistemas silvopastoriles [doctoral thesis]. Buenos Aires: University of Buenos Aires; 2013.

Casanova F, Ramírez L, Solorio F. Interacciones radiculares en sistemas agroforestales: mecanismos y opciones de manejo. Avances en Investigación Agropecuaria 2007; 11(3): 41-52.

Di Rienzo JA, Casanoves F, Balzarini MG, Gonzalez L, Tablada M, Robledo CW. InfoStat versión [online]. Córdoba: Grupo InfoStat; 2013 [cited 2013 Dez 13]. Available from: http://www.infostat.com.ar

Espinosa-García FJ. Revisión sobre la alelopatía de Eucalyptus L'Herit. Boletín de la Sociedad Botánica de México 1996; 58: 55-74.

Fernández ME, Gyenge J, Licata J, Schlichter T, Bond BJ. Belowground interactions for water between trees and grasses in a temperate semiarid agroforestry system. Agroforestry Systems 2008; 74(2): 185-197. http://dx.doi. org/10.1007/s10457-008-9119-4.

Gil RC, Martelotto FE. El agua edáfica: guía práctica para su determinación. Córdoba: INTA; 1993.

Guevara-Escobar A, Cervantes-Jiménez M, Suzán-Azpiri H, González-Sosa E, Saavedra I. Producción de pasto Rhodes en una plantación de eucalipto. Agrociencia 2012; 46(2): 175-188.

Holmgren M, Scheffer M, Huston M. The interplay of facilitation and competition in plant Communities. Ecology 1997; 78(7): 1966-1975. http://dx.doi.org/10.1890/00129658(1997)078[1966:TIOFAC]2.0.CO;2.
Jose S, Gillespie AR, Pallardy SG. Interspecific interactions in temperate agroforestry. Agroforestry Systems 2004; 61-62(1-3): 237-255. http://dx.doi.org/10.1023/ B:AGFO.0000029002.85273.9b.

Massa E, González GL, Rossi CA. Evaluación del pastizal natural en un sistema silvopastoril con sauce (Salix humboldtiana). Pastos y Forrajes 2016; 39: 100-105.

Pezzopane JRM, Bosi C, Nicodemo MLF, Santos PM, Cruz PG, Parmejiani RS. Microclimate and soil moisture in a silvopastoral system in southeastern Brazil. Bragantia 2015; 74(1): 110-119. http://dx.doi.org/10.1590/1678-4499.0334.

Ong CK, Leakey RRB. Why tree-crop interactions in agroforestry appear at odd with tree grass interactions in tropical savannas. Agroforestry Systems 1999; 45(1/3): 109-129. http://dx.doi.org/10.1023/A:1006243032538.

Ospina S, Rusch GM, Pezo DA, Casanoves F, Sinclair FL. More stable productivity of semi natural grasslands than sown pastures in a seasonally dry climate [online]. 2012 [cited 2016 Set 15]. Available from: https://www. semanticscholar.org/paper/More-Stable-Productivityof-Semi-Natural-Grasslands-Ospina-Rusch

Plevich JO, Tarico JC, Fiandino SI, Utello MJ, Prada JD. Producción primaria neta aérea, dinámica del agua y alelopatía en sistemas silvopastoriles del centro de Argentina. In: Llavallol I, editor. Investigación forestal 2011-2015: los proyectos de investigación aplicada. Ciudad Autónoma de Buenos Aires: Ministerio de Agroindustria; Unidad para el Cambio Rural - UCAR; 2016.

Rusch GM, Zapata PC, Casanoves F, Casals P, Ibrahim M, DeClerck F. Determinants of grassland primary production in seasonally-dry silvopastoral systems in Central America. Agroforestry Systems 2014; 88(3): 517-526. http://dx.doi. org/10.1007/s10457-014-9711-8.

Schaller M, Schroth G, Beer J, Jiménez F. Interacciones radiculares entre Eucalyptus deglupta y gramíneas competitivas. Agroforesteria en las Americas 2001; 8(30): 44-47.

Zelada EE, Ibrahim MA. Tolerancia a la sombra de especies forrajeras herbáceas en el trópico húmedo de Costa Rica. Archivos Latinoamericanos de Producción Animal 2005; 5(1): 42-44. 